\title{
Corruption as a factor of national instability and measures to prevent it
}

\author{
Andrey Prorokov ${ }^{1, *}$, Tatyana Fonina ${ }^{1}$ \\ ${ }^{1}$ Moscow Region State University, Radio str., 10A, 105005, Moscow, Russia
}

\begin{abstract}
Corruption in state agencies constitutes a major social threat, since it both directly and indirectly affects social values, morality and national foundations. The level of corruption in a society or a country is the key factor for making a judgment of its civil society development, as well as for estimating its political, economic and social risks. Today, in the age of globalization, corruption is of particularly great concern. This phenomenon is perceived by the authorities of many countries as a deep problem for national security. Moreover, corruption is considered both internal and external threat. Many countries being aware of danger posed by corruption execute consistent works to reduce its rate through introducing and exercising appropriate legislation, which always has prominent national characteristics. On the basis of the legislation adopted in Russia, an integrate and sound system of organizing the activities of civil servants was built, which is able to reduce the corruption rate in the country. However, all measures implemented have not taken any sufficient effect yet. When it is not being constantly tackled, corruption tends to expand and develop, so anti-corruption activities are among the basic functions of any state.
\end{abstract}

\section{Introduction}

When considering corruption as a social downturn, it should be noted that its manifestations entail a number of consequences that exacerbate the existing problems of the society.

Negative economic consequences of corruption include the expansion of a grey economy, leading to the decrease in tax return and the weakening of a state budget; the violation of competitive market mechanisms; inefficient use of state budget funds, particularly when distributing state orders and issuing state loans; increase in the final price for products or services due to "corruption expenses "; deterioration of investment climate.

Negative social consequences of corruption include the defamation of the law as of the main tool regulating the life of a state and society; the diversion of a significant share of public funds from the goals of social development, the extension and preservation of wealth disparity that is rather critical anyhow, the poverty of great part of the population; the escalation of organized crime, the exacerbation of social tension, etc.

\footnotetext{
* Corresponding author: doptaganka@yandex.ru
} 
Negative political consequences of corruption include: the shift of politics' objectives and tasks from nationwide development to ensuring the dominance of corruption groups; the decrease in authorities' credibility, the increase in their detachment from society; the country's image on the world stage is tainted; the decrease in political competition.

Therefore, it can be concluded that there is a threat to the guarantee of political rights and freedoms for all people, the preservation of the constitutional system, the state's legal order and the state itself.

\section{Materials and methods}

The modern understanding of corruption started forming on the cusp of the 17th century, when the processes of building centralized nation states and legal systems corresponding to those states were underway. Significant contribution to the comprehension of corruption problems was made by Niccolo Machiavelli, the outstanding Renaissance philosopher. He considered the corruption as a case when a civil servant uses his public powers for personal interests. Machiavelli compared corruption to a disease that is difficultly recognizable at an early stage, yet is easy to treat, and when this disease is already advanced, it is easy to recognize, but difficult to treat. If the disease is so bad that everyone can notice, then no remedy will help [1].

Since the formation of centralized states in Europe, corruption has been perceived as a major social problem and a sign of an unstable society, which was due to production resources having been developed. Industrialization entailed not only the economic growth, but also the increase in the spectrum of social distribution and the enhancing of authorities' decisions influence. Political power was increasingly becoming a commodity on a rapidly growing market. The victorious bourgeoisie actively tampered with senior officials and often bribed government posts.

The term "corruption" came to Russia from Europe. A.Y. Estrin was the first in Russia who used this word as a legal term in his work. This work, "Bribery" 1913, was a part of activities of a criminal law club at St. Petersburg State University [2].

The majority of researchers narrow the corruption down to bribery and misuse of official position. International organizations define in corruption the same way. For example, in the Code of Conduct for Law Enforcement Officials adopted by the UN General Assembly in 1979, corruption is defined as "misuse of official position to get personal or group benefits, as well as illegal reception of benefits by civil servants associated with their official position" [3].

When discussing corruption, some authors usually point out its political and economic functions. In this case, corruption is determined by the degree of economic and political development, not by a political culture. It reflects the dissension between old and new norms and facilitates the adaptability to changes in all social fields. Certain types of corruption contribute to the formation of important ties in building political coalitions that guarantee social change, and take their part in consolidating or restructuring class differences.

Due to the variety of approaches, it is quite difficult not only to come up with a universal definition of corruption, but also to classify its manifestations in social practice and determine the criteria for this classification.

Situations related to corruption at non-governmental organizations, particularly at international ones, present problems of some extent, as the scandal in the International Football Federation of 2015 of tampering with its functionaries.

At a certain development stage, corruption moves from the stage of separate acts to the stage of system-forming organized networks spread to all directions of state power. In this case, the state and public corruption expenses increase by many times since corruptive 
actions affect the sphere of making decisions, which directly affect national security (development of political decisions, content of legislative and regulatory acts, distribution of government orders, etc.) [4].

While international integrative engagement was becoming deeper, corruption turned into a global problem. Corruption cases are reported almost daily around the world. There is no shortage of scandals that illustrate the depth and destructive power of corruption. This includes informal 'grey' financing of political parties in Europe and North America, bribing high-ranking officials in many countries to obtain large export contracts, imposing death sentences on high-ranking officials in China, squandering of public funds and absence of distinctions between private and public funds, common to some developing countries and emerging economies, etc.

Corruption among senior civil servants led to the changes of governments in Italy, Japan and Brazil at the end of the $20^{\text {th }}$ century and caused political crises in several other countries.

The need in anticorruption efforts made the leading countries develop national systems of anti-corruption legislation. In addition, international anti-corruption agreements were made. In 2003, Russia signed and in 2006 ratified the UN Convention against Corruption of January 27, 1999 (without ratifying Article 20 on illicit enrichment) [5].

Taking into account the significance of this phenomenon, international nongovernmental organization Transparency International developed a corruption perception index (CPI), which is determined through interviewing a large number of experts of various reputable national and international organizations.

Transparency International has been carrying out this research annually since 1995, which allows observing the dynamics of the index. However, it is hard to deny that the proposed methodology for calculating the index leaves the possibility of nonobjective result, since it is the index of perception, which means that it is based on value judgments.

Table 1 shows the indices of Top 10 countries for 2015 and 2019, along with Russia and countries that rank close to Russia and also the CIS countries (the indices of the same countries are given for 2015 to compare them with those for 2019. The index of the most corrupted country is given as well) $[6,7]$.

Corruption manifests differently and has various reasons and effects. The following aspects are of much significance: national characteristics of public mentality, religion, ethnic traditions.

The Netherlands anti-corruption system (8th in the rating) includes procedural and institutional measures: regular reports and transparency in the detection of corruption, a system for monitoring the likelihood of corruption occurrence in state and public organizations, prohibition of working in the government and the loss of all social benefits provided by the public service, creation of internal security services in all valued organizations, particularly in the ministries, the use of mass media when highlighting cases of corruption, etc.

Table 1. Ranking of countries by the corruption perception index [6, 7].

\begin{tabular}{|c|l|c|c|l|c|}
\hline $\begin{array}{c}\text { Rating } \\
\mathbf{2 0 1 9}\end{array}$ & Country & Index & $\begin{array}{c}\text { Rating } \\
\mathbf{2 0 1 5}\end{array}$ & Country & Index \\
\hline 1 & New Zealand & 87 & 1 & Denmark & 91 \\
\hline 1 & Denmark & 87 & 2 & Finland & 90 \\
\hline 3 & Finland & 86 & 3 & Sweden & 89 \\
\hline 4 & Switzerland & 85 & 4 & New Zealand & 88 \\
\hline 4 & Singapore & 85 & 5 & Netherlands & 87 \\
\hline 4 & Sweden & 85 & 5 & Norway & 87 \\
\hline 7 & Norway & 84 & 7 & Switzerland & 86 \\
\hline 8 & Netherlands & 82 & 8 & Singapore & 85 \\
\hline
\end{tabular}




\begin{tabular}{|c|c|c|c|c|c|}
\hline 9 & Luxembourg & 80 & 9 & Canada & 83 \\
\hline 9 & Germany & 80 & 10 & Germany & 81 \\
\hline 11 & Iceland & 78 & 10 & United Kingdom & 81 \\
\hline 66 & Belarus & 45 & 107 & Belarus & 32 \\
\hline 77 & Armenia & 42 & 95 & Armenia & 35 \\
\hline 113 & Kazakhstan & 34 & 123 & Kazakhstan & 28 \\
\hline 120 & Moldova & 32 & 103 & Moldova & 33 \\
\hline 126 & Azerbaijan & 30 & 119 & Azerbaijan & 29 \\
\hline 126 & Ukraine & 30 & 130. & Ukraine & 27 \\
\hline 128 & Kyrgyzstan & 30 & 123 & Kyrgyzstan & 28 \\
\hline 137 & Liberia & 28 & 83 & Liberia & 37 \\
\hline 137 & $\begin{array}{l}\text { Dominican } \\
\text { Republic }\end{array}$ & 28 & 103 & $\begin{array}{l}\text { Dominican } \\
\text { Republic }\end{array}$ & 33 \\
\hline 137 & Paraguay & 28 & 130 & Paraguay & 27 \\
\hline 137 & $\begin{array}{ll}\text { Papua } & \text { New } \\
\text { Guinea } & \\
\end{array}$ & 28 & 119 & Guyana & 29 \\
\hline 137 & Russia & 28 & 119 & Russia & 29 \\
\hline 137 & Lebanon & 28 & 119 & Sierra leone & 29 \\
\hline 137 & Kenya & 28 & 139 & Kenya & 25 \\
\hline 137 & Mauritania & 28 & 112 & Mauritania & 31 \\
\hline 137 & Uganda & 28 & 139 & Uganda & 25 \\
\hline 153 & Tajikistan & 25 & 136 & Tajikistan & 26 \\
\hline 153 & Uzbekistan & 25 & 153 & Uzbekistan & 19 \\
\hline 165 & Turkmenistan & 19 & 154 & Turkmenistan & 18 \\
\hline 180 & Somalia & 9 & 167 & Somalia & 8 \\
\hline
\end{tabular}

Sources: Russia in the corruption perception index -2019: 28 points and $137^{\text {th }}$ place. [Electronic resource] URL: https://transparency.org.ru/research/v-rossii/rossiya-v-indeksevospriyatiya-korruptsii-2019-28-ballov-i-137-mesto.html;

Corruption Perception Index - 2015: Russia climbed to $119^{\text {th }}$ place. [Electronic resource] URL: https://transparency.org.ru/research/indeks-vospriyatiya-korruptsii/indeksvospriyatiya-korruptsii-2015-rossiya-podnyalas-na-119-mesto.html

In Canada (12th place in the rating), legislative measures against corruption in the parliament are defined by criminal and constitutional law and apply to members of both houses of parliament and government. The Canadian Penal Code equates bribery with a violation of the constitution and treason.

In Ireland (18th in the ranking), a government official found to be corrupt is viewed as an enemy of the state in terms of public morality.

The advanced anti-corruption system was created in the USA (23rd place in the rating). American criminal law has a peculiar structure: it consists of federal criminal legislation and criminal codes of each individual state. Both the states and the federal law generally provide for liability for the same types of corruptive misconducts.

Israel (37th place in the ranking) has its anti-corruption experience as well. Due to valued social benefits for officials and imminent punishments of those if the fact of corruption is revealed, there is basically no petty corruption in Israel.

Recently, a strong anti-corruption campaign is being run in China (81 place in the rating): officials at all levels, including the highest level of the government are under close attention of special supervision agencies. 
It is known that petty corruption is almost excluded in such countries as Denmark, Sweden and the Netherlands. Those countries cultivate in public mind an image of an official as a respectable person who is in charge for an important task: to pursue state policy and serve the citizens. Even if an official works in the government, he or she is not replaced when a new prime minister takes up the post. Therefore, the main task of an official is to maintain loyalty to his or her state, not to a specific person.

One of the important elements in anti-corruption activities performed by the leading countries is the compliance of legislation with international standards, which are defined in the OECD (Organization for Economic Cooperation and Development) "Glossary of International Standards in Criminal Law" (2007) [8].

The glossary comprised the principles of three major conventions:

OECD Convention on Combating Bribery of Foreign Public Officials in International Business Transactions (1997);

Criminal Law Convention on Corruption of the Council of Europe (1999);

United Nations Convention against Corruption (2006).

The glossary notes that these conventions altogether provide guidance for creating a sound legislative framework for the combat against corruption.

It should be noted that one of the main trends in reforming public service both in Western (USA, Canada, Great Britain, France, etc.) and in Asian countries (Japan, South Korea, Singapore, etc.) is an increase in the ethical requirements to official activities of public employees.

\section{Results}

In the Russian Federation, a significant outbreak of corruption occurred in the 1990s. Taking into consideration the problem severity, the Government started the formation of a regulatory system to combat corruption. Domestic academicians have developed and phrased the criminological definition of social consequences of crime and the definitions of the consequences of crime in the criminal law.

Numerous studies show that corruption is a real threat to the future of Russia. This is evidenced by data from the files of "Extended Meeting" of the working group that prepared the proposals on the formation of the Open Government system in the Russian Federation on March 22, 2012. These files define corruption as "tax on the future of Russia" with the following specification: "Corruption is an investment and growth tax". Were it not for corruption, Russia's economy could grow at $6 \%$, instead of actual $4 \%$ per year. In 2011, net capital outflows amounted to $4.5 \%$ of GDP, and continued in 2012 despite the favorable external economic situation for Russia; brain drain: the best entrepreneurs and experts cannot apply themselves in their own country because of the high corruption rate [9].

It was noted that corruption is a key factor of social stratification and social tension, since it destroys social mobility and reduces the affordability of high-quality public goods (education, health, security) for the poor.

Corruption is a real threat to the country and its security since a high rate of corruption makes the bureaucracy uncontrollable, increase the share of the grey economy, hampers the development of the infrastructure and the defense complex, impedes the process of resolving environmental problems and does not allow the resolution of inter-ethnic issues.

The initial legal act aimed at combating corruption is the Federal Law on Combating Corruption. This law establishes the basic principles of combating corruption, the legal and organizational foundations of preventing and combating corruption and provides the description of corruption as certain criminal acts [10]. 
In 2008-2012, after ratification of the UN Convention, certain amendments to the existing legislative acts of Russia were made with taking into account of the anti-corruption component.

As part of measures for the legislative ensuring of the combat against corruption, the State Duma adopted a set of regulatory legal acts on December 25, 2008, in a package with the Federal Law "On Combating Corruption". First of all, those acts included the Federal Constitutional Law of December 25, 2008 No. 5-FKZ "On Amendments to Article 10 of the Federal Constitutional Law "On the Government of the Russian Federation".

In Art. 10 of this law, the Chairman of the Government and federal ministers are obliged to additionally provide the tax authorities of the Russian Federation with information on ratable income received, securities, and also ratable property owned by their relatives. Relatives include spouses and minor children, which does not fully reflect the normative definitions provided for by criminal and criminally-remedial legislation.

Another federal law belonging to the package dated December 25, 2008 No. 274-FZ "On Amending Certain Legislative Acts of the Russian Federation" provides for a set of interrelated amendments to a number of federal legislative acts, which is associated with the adoption of Law No. 273-FZ. This list of amended acts include:

The Law of the Russian Federation No. 3231-1 "On the Status of Judges of the Russian Federation" dated June 26, 1992;

Federal laws:

No. 3-FZ "On the status of a member of the Council of the Federation and the status of a deputy of the State Duma of the Federal Assembly of the Russian Federation" (name as amended by the Federal Law of July 5, 1999 No. 133-FZ) dated May 8, 1994,

No. 4-FZ "On the Accounts Chamber of the Russian Federation" dated January 11, 1995 ,

No. 6-FZ "On additional guarantees of social protection of judges and employees of the apparatus of the courts of the Russian Federation" dated January 10, 1996,

dated January 8, 1998 "On the Judicial Department at the Supreme Court of the Russian Federation",

No. 184-FZ "On General Principles of Organization of Legislative (Representative) and Executive Authorities of the Subjects of the Russian Federation" dated October 6, 1999,

No. 30-FZ "On the bodies of the judicial community in the Russian Federation" dated March 14, 2002,

No. 67-FZ "On Basic Guarantees of Electoral Rights and the Right to Participate in the Referendum of Citizens of the Russian Federation" dated June 12, 2002,

dated July 10, 2002 No. 86-FZ "On the Central Bank (Bank of Russia)",

No. 131-FZ "On the General Principles of the Organization of Local Government in the Russian Federation" dated October 6, 2003.

The laws mentioned above impose additional requirements to judges, members of the Federation Council, deputies of the State Duma, deputies of legislative and executive government agencies of constituent entities of the Russian Federation and local governments of municipalities, members of election commissions, the Chairman, Deputy Chairman and auditors of the Accounts Chamber of the Russian Federation and employees of the Bank of Russia.

Many changes introduced in the above-mentioned legislative acts are reasoned by the need to bring the concepts used in them into conformity with new requirements introduced by federal laws adopted during recent years, particularly with the Federal Laws "On the State Civil Service in the Russian Federation".

Some laws determining the activities of power departments were amended. According to these amendments the employees of the public prosecution office, bodies of internal affairs of the Russian Federation, the Federal Security Service, customs authorities, military 
personnel are subject to the restrictions, prohibitions and obligations established by the Federal Law "On State Civil Service in the Russian Federation", with the exception of prohibitions that block them from performing their official duties.

The Labor Code of the Russian Federation is supplemented by the provision that a violation of requirements of the Federal Law "On Combating Corruption" is the basis for terminating the employment contract [11].

In order to eliminate the gaps detected in the legal regulation of deprivation of property, as well as to clarify the concept of "a person performing managerial functions in a commercial or other organization", to strengthen sanctions for abuse of authority and for commercial bribery committed by persons performing managerial functions in a commercial or other organization, the necessary amendments were made in the corresponding articles of the Criminal Code of the Russian Federation (Articles 104.1, 201) [12].

To ensure that Russia complies with its international obligations, Article 285 of the Criminal Code of the Russian Federation is supplemented by a provision enshrining the criminal liability of foreign officials and those of international organizations for the crimes provided for in Ch. 30 of the Criminal Code of the Russian Federation in cases provided for by international treaties of the Russian Federation.

Changes made to the Code of Criminal Procedure of the Russian Federation are aimed at simplifying the procedure for the bringing to criminal responsibility of deputies, judges and other categories of persons who is subject to special procedure for criminal cases [13].

The Code of Administrative Offenses of the Russian Federation is supplemented by norms establishing the liability of legal entities for transferring money, securities or other property by a legal entity (or in its interests) to an official or to a person performing managerial functions in a commercial or other organization, for taking some actions associated with the position of an official or a person performing managerial functions in the interests of this legal entity. The duty to initiate cases of this administrative offense is imposed on a prosecutor. The same norms are aimed at fulfilling Russia's international obligations to establish the liability of legal entities for corruption [14].

In addition, in the context of combating corruption, Federal Law No. 280-FZ of December 25, 2008 amended the second part of the Civil Code of the Russian Federation, Federal Laws of July 25, 1998 No. 128-FZ "On State Fingerprint Registration in the Russian Federation", from July 27, 2004 No. 79-FZ "On the State Civil Service of the Russian Federation".

The relevant regulations of normative legal acts adopted before December 25, 2008 are also directly related to ensuring counteractions against corruption: Federal Laws of December 22, 2008 No. 262-FZ "On Ensuring Access to Information on the Activities of Courts in the Russian Federation" and No. 267-FZ "On Amendments to the Federal Law On Municipal Service in the Russian Federation".

It should be noted that the package of anti-corruption laws obligates state and municipal employees to provide information on their incomes, property and property-related obligations, as well as the same information of their spouse and minor children. Such an approach of the legislator to this problem indicates that all other relatives of officials and public servants are technically not covered by the anti-corruption legislation.

Meanwhile, the Family Code of the Russian Federation refers the following people to family members: spouses, parents and children (including adopted), regardless of their age, imposing the responsibility for taking care of major-aged yet disabled children on their parents [15].

Civil law specifying the term "family members" defines children regardless of their age, spouse and parents as heirs of the first order; heirs of the second order are the full-blood 
and half-blood siblings of the testator, his or her grandparents both on his or her father's mother's side.

The current Criminal Code of the Russian Federation operates with the term "near relative", and the criminal procedure code concretizes it, referring to near relatives the following people: "spouse", "parents", "children", "adoptive parent", "adoptee", "siblings", "grandparents", "grandchildren". The authors assume that such an interpretation of this term is more appropriate and logically relevant for the idea of combating corruption than the one existing in rules of the law package under analysis.

Some experts say that the analysis of federal laws from the package under consideration reveals the fact of not accounting the whole plethora of corruption manifestations existing in the modern reality. As presented, they are not able to fully provide a systematic response to corruption. The content of norms belonging to these laws does not correspond to the provisions of the international anti-corruption acts, which our country signed on to [16].

Russian anti-corruption legislation also provides for creating a number of deliberative coordinating bodies to combat corruption. For instance, there functions the RF Presidential Council for Combating Corruption, which was created on the basis of the Decree.

According to Art. 5 of the Federal Law "On Combating Corruption", bodies may be formed in any constituent entity of the Russian federation by a decision of the President in order to ensure coordination of the activities of federal, regional and local authorities. Such bodies were made at the level of the constituent entities of the federation, both under legislative and executive government agencies, as well as under local self-government agencies of large municipalities. Such deliberative structures were created in some separate departments of the federal and regional levels as well. Their main task is to elaborate measures for preventing corruption in a related territory or within their own department.

The structures mentioned above should not be confused with specific, mainly deliberative agencies created on the basis of the current legislation to resolve certain issues within the framework of the general anti-corruption strategy. Today, the most significant of these agencies are the commissions created on the basis of Art. 19 of Federal Law No. 79FZ dated July 27, 2004 "On the State Civil Service of the Russian Federation" and Decree of the President of the Russian Federation No. 269 dated March 3, 2007 "On Commissions for the Fulfillment of the Requirements to Official Actions of State Civil Servants of the Russian Federation and for the Solution of the Conflict of Interests".

According to the current legislation, a forth part of members these commissions should account for independent experts. They may be specialists working in scientific organizations or educational institutions. All decisions of the commission are advisory.

Despite the impressive regulatory framework for anti-corruption activities and sensational trials executed in recent years, the corruption perception index has been remaining the same for the last five years. Experts believe that the fight against corrupt officials is targeted, the protection of property rights is paid less attention than necessary and the independence of law courts is called into question.

Commenting on the published rating of the corruption perception index for 2019, A. Pominov, the director of the Transparency International Center - R, noted: "In the absence of a political will to make real changes, anti-corruption is doomed to remain a cargo cult. Targeted measures taken by government agencies that are responsible for combating corruption, as well as local amendments made to the legislation, are not able to change the situation in the country radically: for this purposes the inclusive system for reconciling the interests of public actors should be built, which will stop the authorities from making premature decisions serving only the interests of a limited group of people" [6]. 


\section{Discussion}

Currently, the world uses a large number of various ratings that determine the level of socio-economic development of countries, since the classic macro-indicator, gross national product, does not reflect the real condition of a country.

It could be interesting to trace, whether the assessment of corruption affects other rating indices or not. For example, since 2006, there has been defined a prosperity index in order to measure countries' achievements. This ranking has been developed since 2006 by a British analytical center - The Legatum Institute (a division of the international investment firm Legatum). The purpose of the research is to study social well-being and its world-wide development.

The index is compiled on the basis of various indicators, combined into three groups of four parameters, each of which reflects various aspects of society and social welfare:

1. safeguarding and security, personal freedoms, management, social capital;

2. investment environment, state of enterprises, access to markets and infrastructure, economic quality;

3. living conditions, health, education, environment.

For each parameter, the country occupies a specific place, the totality of which determines the place of the state in the ranking. In total, the ranking for 2019 includes 167 countries.

The top ten leaders of this rating expectedly include eight countries from the top ten by the corruption perception index. The spread of rankings according to the assessment of individual parameters ranges between 10-30 points.

Russia ranks 74th (behind Kazakhstan and Belarus, but ahead of Ukraine). At the same time, Russia takes the $20^{\text {th }}$ place by the education parameter, the $43^{\text {rd }}$ place by the parameter of economic quality, then $123^{\text {rd }}$ place by the management parameter, $143^{\text {rd }}$ place by the social capital parameter and 145 place by the parameter of personal freedoms [17].

Such a scatter in the assessment of socio-economic development indicates the lack of consistency and balance of certain aspects of the institutional and social components in the activities of the state.

The end of the prosperity rating is expectedly occupied by those countries that also take last places in the rating of the corruption perception index (Eritrea, Yemen, Afghanistan, South Sudan, Somalia, etc.). Ot can be assumed that the prosperity level of a country depends to some extent on the level of corruption in this country.

\section{Conclusions}

Corruption is deeply rooted in the history and firmly embedded in the state system meanwhile undermining its foundations. Corruption means the acquisitive use of opportunities and powers by officials in their personal interests or in interests of a limited group of people, as well as the receiving of some unrighteous advantages by participants of a corruptive act. The forms of corruption are diverse, the consequences of its spread are detrimental for state's existence, since corruption undermines state's potential capacity for economic and social growth and makes problems for keeping its political stability.

Leading countries are keeping a strong focus on the combat against corruption. They carry out consistent work aimed at reducing corruption through the adoption of relevant legislation and its practical application. Legislation and practice have the pronounced national characteristics and at the same time comply with the principles of international law.

To fight corruption and develop effective national legislation in different countries, it is necessary to have a clear common understanding of international standards. In this regard, 
the official document OECD (Organization for Economic Co-operation and Development) "Corruption. Glossary of International Standards in Criminal Law" (2007).

There are two main aspects of corruption: political and economic. The development of political corruption can make the political situation in the country run out of control. It also poses a threat to democratic institutions and the balance of various government branches. Economic corruption reduces the effectiveness of market institutions and government regulatory activities.

According to information obtained by Transparency International, the greatest success was achieved by the countries of Northern and Central Europe, by New Zealand and Singapore, which traditionally occupy the top lines of the rating dedicated to the corruption perception index. Russia takes a very low place in this rating (in the last third of the list). The results of assessing the leading countries by the Transparency International rating technically can be agreed with, but the methodology for calculating this index is rather controversial. Despite the fact that the methodology for calculating the index is so doubtful and obviously politicized, this assessment cannot be ignored.

According to the World Bank, a key aspect of the combat against corruption is to terminate the underlying factors causing it. Some anti-corruption methods proposed by the international community are as follows:

assisting countries that ask for help in their combat against corruption;

supporting international anti-corruption efforts;

aiming to prevent fraud and corruption in donor-funded projects [18].

Due to its historical development, Russia is largely susceptible to this social disease. Being aware of the danger imposed by corruption on the very sovereignty of Russia, the authorities intensified the works on combating corruption in government agencies at the federal and regional levels. The country has formed a fairly developed regulatory framework aimed at combating corruption.

Despite efforts aimed at combating corruption, Russia is still rated low in the ratings. However, it is not Transparency International's assessment that matters, but the actual situation, which cannot be considered satisfactory.

The main reasons for the low assessment of the corruption perception in Russia and the actual situation in its combat against corruption are the lack of consistency and the formalism of actions, the vagueness of legal punishment norms, the lack of personal responsibility of civil servants, non-publicity, the lack of public control, and ignoring certain principles of international standards in the relevant area.

Meanwhile, there is an understandable correlation between the rate of corruption and the international rating indicators that characterize the level of socio-economic development of the state.

\section{References}

1. N. Makiavelli, Gosudar' (M., INFRA-M, 1999)

2. A.Y. Estrin, Dolzhnostnyye prestupleniya (M., Yuridicheskaya literatura, 1928)

3. Rezolyutsiya 34/169 General'noy assamblei Organizatsii Ob"yedinennykh Natsiy (1979)

4. A.N. Prorokov, Mezhdunarodnyye standarty po problemam korruptsii. Nauchnyye trudy Vol'nogo ekonomicheskogo obshchestva Rossii (M., 2015)

5. United Nations Convention against Corruption: Adopted by Resolution 58/4 at the 51st plenary meeting of the 58th session of the United Nations General Assembly on October 31 (2003)

6. Rossiya $v$ indekse vospriyatiya korruptsii -2019: 28 ballov $i 137$ mesto, 
https://transparency.org.ru/research/v-rossii/rossiya-v-indekse-vospriyatiya-korruptsii2019-28-ballov-i-137-mesto.html.

7. Indeks vospriyatiya korruptsii - 2015: Rossiya podnyalas' na 119 mesto, https://transparency.org.ru/research/indeks-vospriyatiya-korruptsii/indeks-vospriyatiyakorruptsii-2015-rossiya-podnyalas-na-119-mesto.html

8. Korruptsiya. Glossariy mezhdunarodnykh standartov v oblasti ugolovnogo prava. OECD (Organizatsiya ekonomicheskogo sotrudnichestva i razvitiya, 2007)

9. Zasedaniye rabochey gruppy po formirovaniyu otkrytogo pravitel'stva. Medvedev_meeting (2012)/https://ria.ru/Corruption_

10. Federal'nyy zakon ot 25 dekabrya 2008 g. № 273-FZ «O protivodeystvii korruptsii»

11. Trudovoy kodeks Rossiyskoy Federatsii" ot 30.12.2001 N 197-FZ (2019)

12. Ugolovnyy kodeks Rossiyskoy Federatsii" ot 13.06.1996 N 63-FZ (2019)

13. Ugolovno-protsessual'nyy kodeks Rossiyskoy Federatsii" ot 18.12.2001 N 174-FZ (2019)

14. Kodeks Rossiyskoy Federatsii ob administrativnykh pravonarusheniyakh" ot 30.12.2001 N 195-FZ (2019)

15. Semeynyy kodeks Rossiyskoy Federatsii" ot 29.12.1995 N 223-FZ (2019)

16. E. Vasilyeva, A. Mottaeva, E3S Web of Conferences 91, 08051 (2019) doi.org/10.1051/e3sconf /20199108051

17. Reyting stran mira po urovnyu protsvetaniya. Gumanitarnaya entsiklopediya: Issledovaniya (Tsentr gumanitarnykh tekhnologiy, 2006-2020) https:/gtmarket.ru/ratings/legatum-prosperity-index/info 